\title{
ANALYSIS OF NEEDS FOR DEVELOPMENT OF BASIC CONCEPT SOCIAL STUDIES TEACHING MATERIALS IN PRIMARY SCHOOL TEACHER EDUCATION COLLEGE STUDENTS
}

\author{
Muhammad Aunur Rofiq ${ }^{1,}$ Ika Nurwulandari² \\ ${ }^{1}$ Program Studi Pendidikan Guru Sekolah Dasar STKIP Muhammadiyah Blora \\ ${ }^{2}$ Program Studi Pendidikan Guru Sekolah Dasar STKIP Muhammadiyah Blora \\ ${ }^{1}$ muhammadaunurrofiq075@gmail.com, ${ }^{2}$ ikanurwulandari123@gmail.com
}

\begin{abstract}
This study aims to analyze the students' needs for teaching materials in the basic concepts of social studies at STKIP Muhammadiyah Blora. Social studies basic concept courses are subjects that must be implemented by first-semester students of the PGSD STKIP Muhammadiyah Blora Study Program. Currently, the teaching materials used are simple teaching materials made by lecturers without paying attention to student needs. This study uses descriptive qualitative data analysis, namely analyzing the results of observations, interviews, and user questionnaires about the basic concepts of social studies teaching material needs. The research was conducted at the PGSD STKIP Muhammadiyah Blora Study Program. The subjects of this study were the first semester students with a total of 47 students, Primary School Teacher Education Study Program, Basic Concept of Social Sciences courses. The results of data collection indicate that the teaching materials that need to be developed in the Basic Concepts of Social Studies course for PGSD students are textbooks in the form of modules. The development of teaching materials is based on the needs of students, namely on aspects of content/material, aspects of the feasibility of presenting teaching materials, and aspects of language feasibility.
\end{abstract}

Keywords: Analysis, Primary School Teacher Education, Social Studies, Teaching Materials

\begin{abstract}
Abstrak
Penelitian ini bertujuan untuk menganalisis kebutuhan mahasiswa akan bahan ajar pada mata kuliah Konsep Dasar IPS di STKIP Muhammadiyah Blora. Mata kuliah konsep dasar IPS merupakan mata pelajaran yang harus dilaksanakan oleh siswa semester satu Program Studi PGSD STKIP Muhammadiyah Blora. Saat ini bahan ajar yang digunakan adalah bahan ajar sederhana yang dibuat oleh dosen tanpa memperhatikan kebutuhan mahasiswa. Penelitian ini menggunakan analisis data deskriptif kualitatif yaitu menganalisis hasil observasi, wawancara dan angket pengguna tentang konsep dasar kebutuhan bahan ajar IPS. Penelitian dilakukan di Program Studi PGSD STKIP Muhammadiyah Blora. Subjek penelitian ini adalah mahasiswa semester satu dengan jumlah 47 mahasiswa, Program Studi Pendidikan Guru Sekolah Dasar mata kuliah Konsep Dasar Ilmu Sosial. Hasil pengumpulan data menunjukkan bahwa bahan ajar yang perlu dikembangkan dalam mata kuliah Konsep Dasar IPS untuk mahasiswa PGSD adalah buku teks dalam bentuk modul. Pengembangan bahan ajar didasarkan pada kebutuhan siswa yaitu pada aspek isi / materi, aspek kelayakan penyajian bahan ajar, dan aspek kelayakan kebahasaan.
\end{abstract}

Kata Kunci: Analisis, Bahan Ajar, IPS, PGSD

\section{INTRODUCTION}

The development of science and technology must be followed by an increase in the quality of education. Education is a means of developing science and technology that must continue to be developed following the times. The development of models, methods, strategies, 
learning media, and teaching materials is mostly carried out by educators, education students, and education practitioners and aims to improve the quality of learning and the quality of education. Current learning patterns are different from past learning patterns and are not effective in implementation.

The current development affects changes in the mindset and needs of society. The output of the implementation of learning in schools must be adjusted to the needs of the community. The quality of students can be seen from how they respond to a situation or problem encountered in their environment (Salam et al., 2017). Many problems in society must be resolved by using critical and creative thoughts. For this reason, the quality of students must be improved through learning in higher education by applying Higher Order Thinking Skills (HOTS).

The Social Studies Basic Concept is a compulsory subject that must be taken by students of the Primary School Teacher Education Study Program. Social Science (IPS) is a subject that examines a set of events, facts, concepts, and generalizations related to social issues (Badan Standar Nasional Pendidikan (BSNP), 2006). IPS has a very complex purpose and scope. Social studies learning aims to ensure that students have the ability (1) to recognize concepts related to community life and their environment; (2) has the basic ability to think logically and critically, curiosity, inquiry, solve problems, and skills in social life; (3) having commitment and awareness of social and human values; (4) can communicate, cooperate and compete in a pluralistic society, at local, national and global levels.

An effort is needed so that the social studies learning objectives can be achieved. One of these efforts is the use of teaching materials. Teaching materials are an important component in learning that can help students learn.

Teaching materials are all forms of materials used to assist teachers in carrying out learning activities (Muhaimin, 2009). Teaching materials are all forms of materials, information, tools, and texts used to assist teachers/instructors in carrying out teaching and learning activities (Majid, 2007). The materials in question can be written or unwritten materials. Teaching material is a material used to assist teachers in carrying out teaching and learning activities in the classroom (Prastowo, 2012). Teaching materials consist of knowledge, skills, and attitudes that students must learn to achieve predetermined competencies (Kristanto, 2011). Teaching materials consist of two types, namely printed teaching materials (books, printed modules, student worksheets, brochures, leaflets) and non-printed materials (audio, visual, audiovisual, and multimedia). 
Teaching materials are very important in learning activities. For educators, the use of appropriate teaching materials can save time in teaching and can change the role of educators from being a teacher to being a facilitator and can improve the learning process to be more effective and interactive. For students, teaching materials can help students to become independent learners and can be used to measure competencies that have been mastered (Irawati \& Saifuddin, 2018). In learning, student interest and motivation can be increased through interesting teaching materials.

However, based on the facts, there has been no significant increase in the ability of students, both in terms of knowledge, attitudes, and skills. The expected achievement in the Basic Concepts of Social Studies course is not following what is found in learning. The results of the author's interviews with students stated that the basic concepts of social studies course material were still abstract, students had difficulty understanding and applying the knowledge they had learned to solve existing social problems.

Teaching materials are very influential in building understanding because through teaching materials students can re-understand the lecture material given by the lecturer (Dewi \& Afrizon, 2018). There is no teaching material for the Basic Social Studies Concept that is easy to understand and relevant to the abilities they want to achieve. In addition to obtaining material on the basic concepts of social studies from lecturers' explanations in class, students only use teaching materials in the form of textbooks and the internet which are still abstract and difficult to understand. Besides, the examples of problems and assignments provided in the textbook are not following the field of education. So, the teaching materials used by students have not been able to help them understand the basic concepts of social studies properly. Based on the interviews and observations that have been made, another problem that must be considered is the ability of students to solve problems. This can be seen from the low ability of students in analyzing and completing assignments given by lecturers. In general, students have difficulty in carrying out a proper analysis of the problems that are raised in structured assignments, so that the structured assignments have not helped students understand and apply the material.

The solution to overcome this problem is to develop social studies basic concepts teaching materials that are easy to understand, attractive, and appropriate to students' thinking abilities. The teaching materials to be developed contain strategic learning steps that can improve students' ability to solve problems with the right process. The teaching materials developed have characteristics that are relevant to student learning, containing balanced 
concepts, principles, and application of concepts. This teaching material will also contain structured assignments that students can do for problem-solving exercises. Teaching materials that are following the conditions of students will provide meaningful learning experiences for students (Perwitasari et al., 2018).

As a basis for developing teaching materials that contain high-order thinking skills, it is necessary to analyze the teaching material needs needed in learning. The consequences of not discussing social environmental issues in learning result in students not understanding in-depth the real problems. This is exacerbated by the low ability of students' Higher order thinking skills. HOTS is very necessary for environmental learning because environmental problems are complex problems so students need the ability to analyze, evaluate, and create (Ichsan et al., 2019). Students who are taught to develop creative insights into solving problems are better at more complex problem-solving than those who are not (Yee et al., 2015). Through these results, it can be seen what needs to be developed and improved from the teaching materials that have been used. The results of the analysis form the basis for developing better teaching materials.

\section{METHOD}

This study uses research and development, which is research to make products through testing the effectiveness of these products (Sugiyono, 2012). Development method which adapted into four stages, namely the exploration, model development, model testing, and model dissemination and implementation stages (Sukmadinata, 2013). The research procedure carried out by the researcher in this development was adapted from the development steps developed by Borg \& Gall with restrictions. Research procedures make it possible to limit research to a small scale, including limiting the steps of the study (Emzir, 2013).

In this article, the research stage is limited to the needs analysis stage only. Based on this, this article was used to analyze the need for teaching materials for the basic concepts of social studies for students of the Primary School Teacher Education study program.

The data analysis method in this research is using qualitative descriptive data analysis, namely analyzing the results of observations, interviews, and user questionnaires on the basic concepts of social studies teaching material needs. The research was conducted at the Primary School Teacher Education of STKIP Muhammadiyah Blora Study Program which was conducted in the even semester of the 2019/2020 school year. The research subjects were 47 students of STKIP Muhammadiyah Blora who had followed the Basic Concept of Social Studies course. 
Questionnaires are used to determine student needs for the Basic Concepts of Social Studies course. This questionnaire contains how far the learning competencies have been achieved through learning activities so far and students' expectations so that the learning process becomes more effective and efficient.

Needs analysis observation sheet the development of teaching materials contains the following questions; a. How do react students towards the learning process in class? b. What are the deep constraints of Basic Concepts of Social Sciences lectures? c. How the Learning strategy is applied to learning the basic concepts of social studies? d. What study materials have been used on learning the basic concepts of social studies? e. What is the opinion of $\mathrm{Mr} /$ Ms. Lecturer if there is a development of teaching materials that are of a nature independent? f. In the opinion of Mr / Ms. Lecturer what by developing independent teaching materials can add insight and understanding student concept?

The needs analysis questionnaire development of teaching materials for students contains questions as follows; a. What are your sources of learning use to learn the basic concepts of social studies? b. How about a source of learning that siblings want to support learning the basic concept of IPS? c. How the learning strategy is applied in the Basic Concepts of Social Sciences lectures? d. Are the books/study resources that our siblings use today accompanied by pictures interesting and easy to understand? e. What are your suggestions for material development to teach to easily understand the material?

After data analysis was carried out, the author simplifies the development research model in three steps, namely "preliminary study, model development, and model testing. The preliminary study begins with an analysis of the basic concepts of social studies teaching material needs for students. Needs analysis is carried out to obtain information about teaching materials following student needs. Furthermore, the stages in product development consist of four stages, namely; (1) the exploration; (2) model development; (3) model testing; model dissemination, and implementation stages (4) The final stage is product testing.

\section{RESULTS AND DISCUSSION}

\section{Results}


This search aims to analyze the needs of students for the basic concepts of social studies teaching materials. Textbooks are a type of teaching material that can be used as a guide for students and lecturers in lecturing activities. The development of textbooks is tailored to the curriculum and the needs of students, uses language that is easy to understand, and there is a feedback mechanism from students. Teaching materials are a set of learning tools or tools that contain learning materials, methods, limitations, and ways of evaluating which are designed systematically and attractively to achieve competencies or sub-competencies with all their complexities (Ruhimat, 2011).

Based on data collection in the form of observations and questionnaires, the results are obtained; 1) Some students are not active in learning; 2) Learning centered on lecturers; 3) Lecturers do not have handbooks as teaching materials; 4) The source of student learning comes from presentation papers and the internet; 5) Students have not focused on the learning process because they do not have a reference book to use.

The factor causing the above is that students have not used the teaching materials used by students for learning. The nothing of teaching materials makes students not pre-pare material to be discussed in learning, so the students are not active in discussions or questions and answers.

Also, the results of observations about the types of learning resources used by students were only presentation papers and the internet. Furthermore, filling out a questionnaire about the type of student teaching materials desired by students showed that $30.97 \%$ wanted modules, $36.56 \%$ wanted textbooks, $22.38 \%$ wanted handouts, $10.09 \%$ wanted Student Worksheets. Next, students fill out a questionnaire about the teaching materials needed by students. The need for developing these teaching materials is explained as follows.

a) Content / material aspects

In the aspect of content/material feasibility, students want Social Studies Basic Concepts teaching materials that contain the following content/material.

1) Material Resources

The material sources come from various sources, in the form of existing reference books and from the internet.

\section{2) Coverage of material}

The scope of material includes basic social science concepts, values, attitudes, and skills in social studies, facts, concepts, and generalizations. 
3) Introductory Material

Introductory material serves to provide an initial description of the material to be studied.

4) Type of Material

The type of material students want is material that trains students to think critically (higher-order thinking skills).

5) Material Characteristics

The characteristics of the material are easy to understand, interesting, and motivate students to learn.

6) Content of the Material

The material in teaching materials is accompanied by examples and exercises in the form of additional information related to problems in the community and the surrounding environment so that it can train students to think critically.

b) Presentation Aspects of the Material

From the aspect of the feasibility of content, students want Social Studies Basic Concepts teaching materials that contain the following contents

1) Presentation Systematic

Students want a systematic and coherent presentation of teaching materials. The presentation systematic includes titles, introductions, manuals for the use of books, table of contents, introduction, material, examples, exercises, and bibliography.

2) Presentation of Instructions for Use

Students want instructions for use to guide them when studying. The presentation of these manuals includes manuals for the use of books and book concept maps. The teaching material is also equipped with pictures of instructions.

3) Presentation of illustrations

Students want to present illustrations that include illustrations in the form of stories and pictures. The presentation of the stories and pictures must be relevant and can support student understanding. With illustrations, descriptions can be made shorter, clearer, focused, and interesting.

4) Presentation of the Material

Students want the presentation of material that is coherent, easy to understand, interesting, and creative. 
5) Presentation of Examples

Students want examples of material in the environment. This is intended so that students understand better the material being studied. These examples can provide a real picture for students so that they can apply the material in real life. The number of samples that students want is adjusted to the material.

6) Presentation of Evaluation

Evaluation is given to measure student learning outcomes in both the cognitive and psychomotor domains.

7) Presentation of Terms

The presentation of the terms used in teaching materials according to students is explained directly in the material. Also, to make it easier to find the meaning of the terms used in teaching materials, a glossary is added at the end of the book.

8) Presentation of Bibliography

The bibliography is part of the completeness of the contents of the book. A list of references to material sources used in teaching materials in the bibliography. It is intended that users, both students and lecturers, and other parties, can find out what sources of material are used. In teaching materials, the bibliography is presented at the end of the book.

9) Presentation of Author Biographies

This author's biography contains background information about the author of the book. It is intended that readers can find out the information about the author of the book. This author's biography is presented at the end of the book after the presentation

c) The aspect of Language Eligibility

The aspects of linguistic feasibility in developing teaching materials for the basic concepts of social studies are described as follows.

1) The language used is following the level of knowledge and the development level of students' thinking abilities (clear vocabulary, correct diction, and correct spelling).

2) The language used in creative writing material is following the socio-emotional situation of students

3) The material is written following the rules of Indonesian which are good and correct

4) The material is written by paying attention to the rules of sentence structure.

5) The material is written using effective sentences.

6) The language used is communicative. 
7) The terms used are easy to understand.

\section{Discussion}

This discussion is about the findings and results of the analysis of teaching material needs. Basic Concepts of Social Sciences at Primary School Teacher Education STKIP Muhammadiyah Blora students. Based on observations, the results obtained that 1) Some students are not active in learning; 2) Learning centered on lecturers; 3) Lecturers do not have handbooks as teaching materials; 4) The source of student learning comes from presentation papers and the internet; 5) Students have not focused on the learning process because they do not have a reference book to use. Teaching materials can act as independent learning materials if they are developed completely (Hernawan et al., 2012). Teaching materials are equipped with learning objectives, learning materials described in learning activities, media illustrations, learning procedures, exercises equipped with answer signs, formative tests with answer keys, feedback, and bibliography. To increase the effectiveness of its users, teaching materials musthave criteria that must exist (Widodo, 2008).

Based on research data, it is necessary teaching materials are developed in the form of modules. The module was chosen because it can facilitate students to study with an educator or independently. The module is one of the teaching materials designed systematically based on certain curriculum and packaged in units the smallest learning and can be learned independently in a certain time unit (Purwanto, Aristo R., 2007). Modules are teaching materials arranged systematically by topic discussion and competence that must be achieved in learning (Ardiansyah et al., 2016). Learning systems using modules will make learning more effective, efficient, and relevant (Made, 2011). Learning by modules self-learning which provides student opportunities to manage study time and understand the lecture material independently.

Modules being developed educators adapted to the characteristics of students, such as the social, cultural, geographic, initial skills mastered, interests, as well as student backgrounds. The development of this module can answer and solve the problem in learning. Some material learning is often difficult to understand it is understood by students. This difficulty can also occur due to abstract material. As well as complicated material, it can be explained in a way that simple, according to the level of thinking of students. The module can facilitate students (students) more interested in learning and can improve learning outcomes (Depdiknas, 2008).

The use of teaching materials in the learning process has an important role. This role includes roles for teachers, students, in classical, individual, and group learning (Belawati, 
2003). To obtain a clearer understanding, each role will be explained as follows: For the Teacher; Teaching materials for teachers have a role, namely: 1) Save teacher time in teaching The existence of teaching materials, students can be assigned to study the topic or material to be studied in advance so that the teacher does not need to explain in detail anymore; 2) Changing the teacher's role from being a teacher to being a facilitator. The existence of teaching materials the role of the teacher is to facilitate students as the delivery of subject matter; 3 ) Improve the learning process to be more effective and interactive. With teaching materials, learning will be more effective because teachers have a lot of time to guide their students in understanding a learning topic, and also the methods they use are more varied and interactive because teachers do not tend to lecture. For students; Teaching materials for students have a role, namely: 1). Students can learn without the presence / there must be a teacher; 2) Students can study whenever and wherever they want; 3) Students can learn at their own pace; 4) Students can study in the order of their choosing; 5) Helping the potential to become independent learners. In Classical Learning, teaching materials have roles, namely: 1) Can be used as an inseparable material from the main book; 2) Can be used as a complement to the main book; 3) can be used to increase student motivation; 4) can be used as a material that contains an explanation of how to find applications, relationships, and linkages between one topic and another. In Individual Learning; teaching materials have a role, namely: 1) as the main media in the learning process; 2) tools used to compile and supervise the process of students obtaining information; 3) supporting other individual learning media. In Group Learning; teaching materials have a role, namely: 1) as an integrated material with the group learning process; 2) as supporting material for the main learning material. Teaching material is a set of subject matter that refers to the curriculum used to achieve predetermined competency standards and basic competencies (Ika Lestari, 2013).

\section{CONCLUSION}

The conclusion from this research is that the obstacles faced in learning the Basic Concept of Social Studies course are that no teaching material can be used as a guide in the learning process. Teaching materials that need to be developed in the Basic Concepts course for elementary school teacher education students are textbooks. The development of teaching 
materials is based on student needs, namely in the content/material aspect, the feasibility aspect of the presentation of teaching materials, and the aspect of linguistic feasibility.

\section{ACKNOWLEDGMENTS}

Our gratitude goes to all parties involved in this research especially to Kementerian Riset Pendidikan Tinggi. Our thanks also go to STKIP Muhmammadiyah Blora who gave their time in this study. Then, our thanks go to the PrimaryEdu journal team who allowed us to be able to publish in their journals.

\section{REFERENCES}

Ardiansyah, R., Corebima, A. D., \& Rohman, F. (2016). Analisis Kebutuhan Pengembangan Bahan Ajar Perubahan Materi Genetik pada Matakuliah Genetika di Universitas Negeri Malang. Seminar Nasional Pendidikan Dan Saintek 2016.

Badan Standar Nasional Pendidikan (BSNP). (2006). Standar Isi Untuk Satuan Pendidikan Dasar dan Menengah: Standar Kompetensi dan Kompetensi Dasar SMA / MA. Jakarta: BSNP.

Belawati, T. (2003). Pengembangan Bahan Ajar (1st ed.). Pusat Penerbitan Universitas Terbuka.

Depdiknas. (2008). Penulisan Modul. Penulisan Modul.

Dewi, W. S., \& Afrizon, R. (2018). Analisis Kondisi Awal Perkuliahan Mahasiswa Pendidikan Fisika Dalam Rangka Mengembangkan Bahan Ajar Statistika Pendidikan Fisika Menggunakan Model Problem Solving. JURNAL EKSAKTA PENDIDIKAN (JEP). https://doi.org/10.24036/jep/vol2-iss1/140

Emzir. (2013). Metodologi Penelitian Pendidikan:Kuantitatif dan Kualitatif (7th ed.). Raja Grafindo Persada.

Hernawan, A. H., Permasih, \& Dewi, L. (2012). Pengembangan Bahan Ajar Tematik. In Direktorat UPI Bandung.

Ichsan, I. Z., Sigit, D. V., \& Miarsyah, M. (2019). Environmental Learning based on Higher Order Thinking Skills: A Needs Assessment. International Journal for Educational and Vocational Studies. https://doi.org/10.29103/ijevs.v1i1.1389

Ika Lestari. (2013). Pengembanagn Bahan Ajar Berbasis Kompetensi. Padang: Akademia Permata.

Irawati, H., \& Saifuddin, M. F. (2018). Analisis Kebutuhan Pengembangan Bahan Ajar Mata Kuliah Pengantar Profesi Guru Biologi Di Pendidikan Biologi Universitas Ahmad Dahlan Yogyakarta. Bio - Pedagogi: Jurnal Pembelajaran Biologi.

Kristanto, D. D. (2011). PengembanganModulFisika RSBI Pokok Bahasan Gerak Pada

64 | ANALYSIS OF NEEDS IN THE DEVELOPMENT OF TEACHING MATERIALS BASIC CONCEPT OF SOCIAL STUDIES FOR PRIMARY SCHOOL TEACHER EDUCATION 
Siswa SMA Kelas X Semester 1 SMA Negeri 1 Purwareja Klampok. Universitas Negeri Semarang.

Made, W. (2011). Strategi Pembelajaran Inovatif Kontemporer: Suatu Tinjauan. Konseptual Operasional. Jakarta: PT. Bumi Aksara.

Majid, A. (2007). Perencanaan Pembelajaran (Mukhlis (ed.); 2nd ed.).

Muhaimin. (2009). Modul Wawasan Pengembangan Bahan Ajar bab V Malang. LKP2-I.

Perwitasari, S., Wahjoedi, \& Sa'dun, A. (2018). Pengembangan Bahan Ajar Tematik Berbasis Kontekstual. Jurnal Pendidikan: Teori, Penelitian, Dan Pengembangan.

Prastowo, A. (2012). Panduan Kreatif Membuat Bahan Ajar Inovatif Menciptakan metode pembelajaran yang menarik dan menyenangkan (D. Wijaya (ed.); 4th ed.). Diva Press.

Purwanto, Aristo R., S. L. (2007). Pengembangan Modul. Departemen Pendidikan Nasional, Pusat Teknologi Informasi dan Komunikasi Pendidikan.

Ruhimat. (2011). Kurikulum dan Pembelajaran. Rajawali Press.

Salam, R., Akhyar, M., Tayeb, A. M., \& Niswaty, R. (2017). Peningkatan Kualitas Publikasi Ilmiah Mahasiswa dalam Menunjang Daya Saing Perguruan Tinggi. Jurnal Office. https://doi.org/10.26858/jo.v3i1.3463

Sugiyono. (2012). Metode Penelitian Kuantitatif, Kualitatif dan R \& D.Bandung:Alfabeta. Metode Penelitian Kuantitatif, Kualitatif Dan R \& D.Bandung:Alfabeta. https://doi.org/10.1017/CBO9781107415324.004

Sukmadinata, N. S. (2013). Metode Penelitian Pendidikan (9th ed.). PT Remaja RosdaKarya.

Widodo, C. S. (2008). Panduan Menyusun Bahan Ajar Berbasis Kompetensi. Elex Media Komputindo.

Yee, M. H., Jailani, M. Y., Widad, O., Razali, H., Tee, T. K., \& Mohaffyza, M. M. (2015). The Effectiveness of Higher Order Thinking Skills for Generating Idea among Technical Students. Recent Advances in Educational Technologies. 